\title{
Albinterferon Alfa-2b
}

National Cancer Institute

\section{Source}

National Cancer Institute. Albinterferon Alfa-2b. NCI Thesaurus. Code C87296.

A long-acting, recombinant fusion polypeptide consisting of interferon alpha- $2 \mathrm{~b}$ (IFNa-

2b) linked to human albumin (alb-IFN), with antiviral and immunomodulatory activity.

Albinterferon alpha-2b binds to specific cell-surface receptors, resulting in the expression

of genes whose protein products mediate antiviral, antiproliferative, and immune-

modulating effects. Conjugation of interferon to human albumin prolongs the half-life of IFNa-2b and thereby allows for a reduction in the frequency of dosing. 